\title{
Role of H3K27 Demethylases Jmjd3 and UTX in Transcriptional Regulation
}

\author{
M.R. HÜBNER AND D.L. SPECTOR \\ Cold Spring Harbor Laboratory, Cold Spring Harbor, New York 11724 \\ Correspondence: huebner@cshl.edu; spector@cshl.edu
}

\begin{abstract}
The influence of histone amino-terminal covalent modifications on gene regulation has drawn intense research efforts in recent years. It is now clear that activating and inactivating modifications have a key role in determining the gene-expression profile of an individual cell or cell lineage. Thus, differences in these modifications have a pivotal role in determining and maintaining cell fate during development. The interplay of histone methyltransferases (HMTs) and demethylases confers the plasticity necessary for changes in the gene-expression profile of a cell during differentiation or changes following environmental cues. The histone H3 lysine 27 (H3K27) demethylases Jmjd3 and UTX remove the gene-inactivating H3K27 dimethyl and trimethyl marks and are involved in inducing and/or maintaining gene expression. In this chapter, we highlight the role of the H3K27 demethylases Jmjd3 and UTX in gene expression.
\end{abstract}

Transcriptional repression of individual genes, which is established as a result of a developmental process or cellular differentiation, is generally maintained throughout the lifetime of a cell. Importantly, these gene-expression patterns are propagated to the daughter cells, thereby providing a cellular memory for the differentiation decisions made in their progenitors. For instance, the expression patterns of $H O X$ genes are established during early body-plan formation and maintained in the active or inactive state by Trithorax and Polycomb proteins, respectively (for review, see Schuettengruber et al. 2007; Schwartz and Pirrotta 2007). Many of these gene-expression patterns are maintained for several decades in the case of animals or even for centuries in some plants. However, to allow plasticity during a developmental program or in response to environmental cues, gene silencing needs to be reversible.

Gene silencing by the Polycomb group (PcG) of proteins involves trimethylation of lysine 27 in the amino-terminal tail of histone $\mathrm{H} 3$ and is involved in mammalian X-chromosome inactivation, stem cell identity, and germline development (Plath et al. 2003; Zhao et al. 2008; Schuettengruber and Cavalli 2009). The enzyme to catalyze H3K27 trimethylation in differentiated cells is Ezh2 (enhancer of zeste homolog 2), which, together with its essential cofactor EED as well as SUZ12 and RbAp48, are part of the Polycomb repressive complex 2 (PRC2) (for review, see Simon and Kingston 2009). The Ezh2 homolog Ezh1 forms a distinct PRC2 complex that maintains H3K27me3 modification and repression of developmental target genes (Margueron et al. 2008; Shen et al. 2008). However, Ezh1 is present at lower levels than Ezh2 in actively dividing cells and has a weaker methyltransferase activity (Margueron et al. 2008). H3K27me3 is recognized by the chromo domain of the Polycomb protein in Drosophila or its orthologs in mammalian cells. Polycomb, together with Bmil and the H2A ubiquityl ligase RING1B, is a member of PRC1, which mediates chromatin compaction and, ultimately, gene silencing (Francis et al. 2004).

The closely related Jmjd3 (Kdm6B [jumonji-domaincontaining protein 3]) and UTX (KDM6A [a ubiquitously transcribed tetratricopeptide repeat gene on the $\mathrm{X}$ chromosome]) are members of a growing number of Fe(II) and $\alpha$-ketoglutarate-dependent demethylases containing a conserved Jumonji C (JmjC) domain (the jumonji gene was named for a mutation in mice that causes abnormal cruciform neural grooves (in Japanese, jumonji means cruciform) (see Fig. 1) (for review, see Klose et al. 2006; Lan et al. 2008; Mosammaparast and Shi 2010). To date, $30 \mathrm{JmjC}$-domain-containing proteins are known in human and mouse, most of which possess demethylase activity to a number of different histone and nonhistone substrates (Huang and Berger 2008). Only LSD1/KDM1a, which balances promoter $\mathrm{H} 3 \mathrm{~K} 4 / \mathrm{H} 3 \mathrm{~K} 9$ methylation for activation or repression of its target genes, and its homolog LSD2/KDM1b, which modulates intragenic H3K4 dimethylation, do not contain a JmjC domain (Shi et al. 2004; Klose and Zhang 2007; Shi and Whetstine 2007; Cloos et al. 2008; Fang et al. 2010). Both Jmjd3 and UTX have been shown to demethylate H3K27me2/3 (Agger et al. 2007; De Santa et al. 2007; Hong et al. 2007; Lan et al. 2007; Lee et al. 2007). UTX is located at Xp11.2 on the $\mathrm{X}$ chromosome, escapes $\mathrm{X}$-chromosome inactivation, and is ubiquitously expressed (Greenfield et al. 1998). UTX and its male homolog UTY, which shares $83 \%$ amino acid identity (Greenfield et al. 1998), but not $\mathrm{Jmjd} 3$, contain tetratricopeptide repeats in their amino-terminal region that are assumed to mediate protein-protein interactions (Blatch and Lassle 1999). All three proteins have a carboxy-terminal treble-clef zinc finger. 

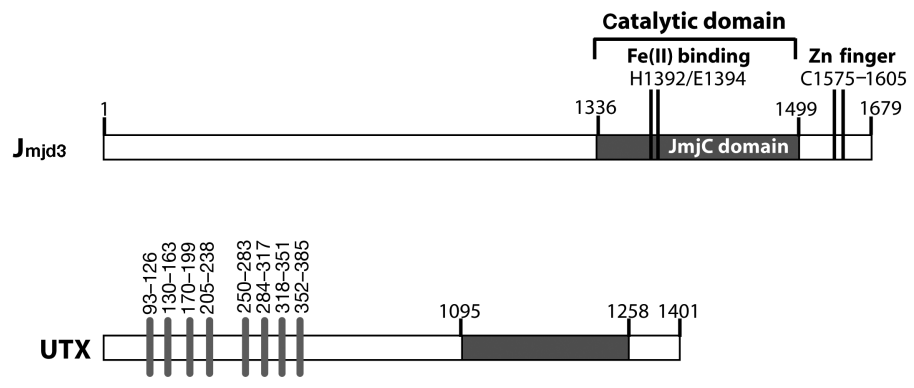

Figure 1. Protein domains of human Jmjd3 and UTX. (Dark gray) Catalytic JmjC domain (horizontal), (light gray) tetratricopeptide repeats (vertical). Indicated also are the Fe(II) binding site and zinc finger. Numbers indicate amino acid positions.

\section{H3K27 DEMETHYLASES IN DIFFERENTIATION}

In undifferentiated ES cells, the promoter of many key developmental genes is marked by H3K27me3 (Boyer et al. 2006; Bracken et al. 2006; Lee et al. 2006; Pan et al. 2007). These promoters often carry the activating H3K4 mark as well and are thus called "bivalent" (Bernstein et al. 2006; Mikkelsen et al. 2007; Pan et al. 2007; Zhao et al. 2007; Ku et al. 2008). The presence of the H3K27me3 modification keeps these developmental regulators repressed or expressed at very low levels and is believed to keep them poised for rapid activation once the appropriate signal is received and the repressive mark is removed (Bernstein et al. 2006). At the end of ES cell lineage commitment, these bivalent domains have been resolved to carry either activating (H3K4me3) or inactivating (H3K27me3) marks in a lineage-specific manner (Bernstein et al. 2006). In ES cells, the pluripotency genes $O C T 4, S O X 2$, and $N A N O G$ are rich in trimethylated $\mathrm{H} 3$ lysine 4 (H3K4me3,) which is generally associated with active genes. These genes acquire the H3K27me3 mark as they get repressed during differentiation (Pan et al. 2007).

During embryonic development, Nodal signaling activates Smad2 and Smad3, which get recruited to H3K27 trimethylated and PcG-silenced target genes (Dahle et al. 2010). Smad2/3 then recruit Jmjd3, which leads to the loss of $\mathrm{H} 3 \mathrm{~K} 27 \mathrm{me} 3$, dissociation of PRC2 components, and ultimately, derepression of target genes, e.g., the Brachyury locus in ES cells (Dahle et al. 2010).

Jmjd3, but not UTX, is required for neural commitment in the differentiation of mouse ES cells into neural stem cells in adherent monocultures (Burgold et al. 2008). Together with four other JmjC genes (Jmjd2b, Jaridla, Jaridl 1 , and $P h f 8$ ), Jmjd3 is up-regulated in differentiating neural precursors at day 8 of differentiation but down-regulated in self-renewing neural stem cells at day 26 (Burgold et al. 2008). Jmjd 3 gets recruited to the transcriptional start site of Pax6 (a homeodomain transcription factor), Nestin (a neurofilament protein), and Soxl (a homeodomain protein with a key role in neural commitment), and depletion of the Jmjd3 protein leads to decreased up-regulation of these genes (Burgold et al. 2008). Jmjd3 resolves the bivalent status of the Nestin promoter by demethylating H3K27 and thus activating Nestin expression, which is a key regulator and marker of neurogenesis (Burgold et al. 2008). In contrast, the initial recruitment of Jmjd 3 to the
Pax6 transcriptional start site does not result in decreased H3K27me3 levels. This indicates that Pax6 can be expressed in the presence of $\mathrm{H} 3 \mathrm{~K} 27 \mathrm{me} 3$ and the demethylase activity of Jmjd3 might be regulated and context specific. Similarly, genome-wide studies showed that certain genes can be expressed despite H3K27me3 in their promoter region (Ringrose and Paro 2004; Bracken et al. 2006; Papp and Muller 2006; Roh et al. 2006). Following Jmjd3 depletion, Pax6 up-regulation is impaired, indicating that Jmjd 3 contributes to Pax6 expression through a mechanism that is independent of its $\mathrm{H} 3 \mathrm{~K} 27$ demethylase activity or that the involvement of Jmjd3 is indirect (Burgold et al. 2008).

During neural differentiation, global H3K27me3 levels, as well as levels of H3K9me3 and H4K20me3, increase (Akizu et al. 2010), and a number of genes become repressed by the H3K27me3-dependent PcG machinery (Boyer et al. 2006; Lee et al. 2006; Pietersen and van Lohuizen 2008). Interestingly, the maintenance of global H3K27me3 levels is not required for neural differentiation or neuroblast proliferation (Akizu et al. 2010). However, in the developing spinal cord, dorsal interneuron generation is regulated by $\mathrm{H} 3 \mathrm{~K} 27 \mathrm{me} 3$-dependent repression of the Noggin promoter. Noggin is an extracellular inhibitor of bone morphogenetic proteins (BMPs), which are essential for the formation of dorsal neural cell types (Liu and Niswander 2005). In turn, BMPs activate Noggin expression, thereby creating a negative regulatory feedback loop. Noggin activation by BMP is mediated by Smad1/4-dependent H3K27 demethylation of the Noggin promoter by Jmjd3 (Akizu et al. 2010).

As a result of retinoic acid (RA)-induced neuronal differentiation in P19 cells, Jmjd3 expression, but not UTX, increases and has a role in activating the Mashl/Ascll gene through Hes1-dependent binding to the Mash1 promoter (Dai et al. 2010). Similarly, Jmjd3 is involved in the RA- or Notch-dependent induction of differentiation along the neuronal pathway and subsequent forebrain development in the mouse (Jepsen et al. 2007). In the absence of ligand, RA-dependent differentiation along the neuronal pathway is repressed by the nuclear receptor corepressor 2 (NCoR2, also known as SMRT). SMRT acts by repressing the expression of Jmjd3, which prevents the up-regulation of genes involved in neuronal differentiation. Conversely, the Jmjd3 gene is a direct target of the liganded RA receptor, which causes the up-regulation of Jmjd3 during RA-induced neural differentiation (Jepsen 
et al. 2007). Similarly, overexpression of Jmjd3, but not a catalytically inactive mutant, results in the induction of neuronal genes (Jepsen et al. 2007). The opposing functions of SMRT and the RA receptor are mediated by their competitive binding to the canonical RARE (retinoic acid response element) region in the Jmjd3 promoter region (Jepsen et al. 2007).

Jmjd3 is the only JmjC-domain-containing protein that is up-regulated by lipopolysaccharide (LPS) stimulation and transdifferentiation of mouse macrophages. This up-regulation depends on the binding of NF- $\kappa \mathrm{B}$ to conserved NF$\kappa \mathrm{B}$-binding sites located in the promoter region just upstream of the transcription start site of the Jmjd3 gene in macrophages (De Santa et al. 2007). Conversely, the Jmjd3 paralog UTX, which shares $84 \%$ of sequence similarity in the JmjC domain (Hong et al. 2007), is expressed at low and constant levels. Jmjd3 is involved in up-regulating the Bmp-2 gene by reducing H3K27me3 levels in mouse macrophages 8-24 h postinduction with LPS (De Santa et al. 2007). Similarly, the HOXA11 and Irf4 genes are Jmjd3 targets in differentiating bone marrow cells (De Santa et al. 2007; Satoh et al. 2010). Jmjd3 is in a complex with the H3K4 HMT MLL/Trx2 (but not MLL1) as well as with the MLL complex components Wdr5, RbBP5, and Ash2L (De Santa et al. 2007). Conversely, UTX was found to bind to MLL2/ALR (Issaeva et al. 2007). This suggests that gene expression can be facilitated by a combination in the same complex of enzymes that add the activating H3K4me3 mark and remove the repressive $\mathrm{H} 3 \mathrm{~K} 27 \mathrm{me} 3$ modification. Indeed, Jmjd 3 gets recruited to $>70 \%$ of LPS-induced genes, where it preferentially binds to promoters that carry high levels of H3K4me3 (De Santa et al. 2009). More specifically, Jmjd 3 binds to a region within $2.5 \mathrm{~kb}$ of the transcriptional start site, and its binding peaks after $2 \mathrm{~h}$ of LPS stimulation. Interestingly, most of the Jmjd3 target genes are not associated with H3K27me3. Furthermore, the Jmjd3 target genes that had H3K27 methylation before stimulation did not show a statistically significant decrease in H3K27 methylation after stimulation (De Santa et al. 2009). The deletion of Jmjd3 did not affect the expression of most of its target genes, suggesting redundancy and/or additional functions of Jmjd3. However, in a few hundred Jmjd3 target genes, polymerase II (Pol II) recruitment and transcription were moderately impaired (De Santa et al. 2009). Furthermore, overall levels of H3K27me1-3, as well as that of $\mathrm{H} 3 \mathrm{~K} 4 \mathrm{me} 1-3$ in fetal-liver-derived macrophages from wildtype and $\mathrm{Jmjd}^{-/-}$mice, were identical, indicating that H3K27 methylation does not undergo continuous turnover (De Santa et al. 2009).

The hematopoietic T-box transcription factor T-bet has a role in the differentiation of naïve $\mathrm{CD}^{+} \mathrm{T}$ cells into the T-helper type-1 (Th1) lineage. The differentiation of CD4 ${ }^{+}$ $\mathrm{T}$ cells into the Th1 lineage is accompanied by $\mathrm{H} 3 \mathrm{~K} 27$ demethylation and $\mathrm{H} 3 \mathrm{~K} 4 \mathrm{me} 2$ modification of the interferon- $\gamma($ Ifn- $\gamma)$ gene, whereas differentiation into the Th2 lineage is accompanied by silencing of the Ifn- $\gamma$ locus by the H3K27me3 mark (Schoenborn et al. 2007). The activation of the Ifn- $\gamma$ locus is mediated by direct interaction of T-bet with the H3K27 demethylase Jmjd3 and the H3K4 HMT Set7/9 (Lewis et al. 2007; Miller et al. 2008). Fur- thermore, Jmjd3 is involved in the transcriptional activation of specific marker genes of alternatively activated (M2) macrophages (Ishii et al. 2009).

Stem cell self-renewal and differentiation are balanced in the human epidermis, which has a turnover rate of $\sim 4$ weeks and undergoes continual replenishment from stem cells of the inner epidermal basal layer. Concomitant with differentiation, these cells exit the cell cycle, detach from the basal membrane, and migrate outward (for review, see Blanpain and Fuchs 2006). Genes involved in differentiation are suppressed in undifferentiated cells and induced during epidermal differentiation. This process involves the Jmjd3-dependent loss of H3K27me3 at the promoter regions as well as SUZ12 binding to the promoters of the induced genes (Sen et al. 2008). Consequently, overexpression of Jmjd3 or depletion of SUZ12 or Ezh2 leads to premature epidermal differentiation, whereas depletion of Jmjd3 prevents epidermal differentiation (Sen et al. 2008). Another example for the reprogramming of skin cells is the induction of a large repair transcriptome during wound healing in murine skin repair, which is associated with a loss of Polycomb-mediated gene silencing and an up-regulation of Jmjd3 and UTX (Shaw and Martin 2009).

UTX mediates the demethylation of H3K27me3 of the muscle-specific myogenin (Myog) and muscle creatine kinase $(\mathrm{CKm})$ genes during myogenesis (Seenundun et al. 2010). Demethylation is initially mediated through UTX binding to the homeobox transactivator Six4, which leads to loss of $\mathrm{H} 3 \mathrm{~K} 27 \mathrm{me} 3$ in the region upstream of the transcription start site (Seenundun et al. 2010). Subsequent H3K27 demethylation in the coding region requires elongating RNA Pol II (Seenundun et al. 2010), and Drosophila UTX has been shown to directly associate with Ser-2phosphorylated elongating Pol II on actively transcribed genes (Smith et al. 2008).

\section{REGULATION OF HOX GENES BY H3K27 DEMETHYLASES}

RA-induced differentiation of human pluripotent embryonal NT2/D1 teratocarcinoma cells into neural lineages is associated with UTX binding to $H O X A 1-3$ and HOXB1-3 genes and subsequent $\mathrm{H} 3 \mathrm{~K} 4$ methylation, H3K27 demethylation, and loss of PRC2 binding (Agger et al. 2007; Lee et al. 2007). Interestingly, the recruitment of Ash2L and H3K4 trimethylation occurred $18 \mathrm{~h}$ postRA administration, whereas UTX binding and H3K 27 demethylation took 24 hours (Lee et al. 2007). This suggests that the interplay of these opposing activities regulates the transcriptional activation of $H O X$ gene promoters. Consequently, disruption of the Caenorhabditis elegans Jmjd3 homolog XJ193 led to defects in gonadal development and organization (Agger et al. 2007). Similarly, in HEK293 cells, UTX was shown to bind to the HOX gene cluster in a complex with MLL3/4 (ALR), which leads to demethylation of $\mathrm{H} 3 \mathrm{~K} 27 \mathrm{me} 2 / 3, \mathrm{H} 3 \mathrm{~K} 4$ methylation, and the loss of PRC1-mediated transcriptional repression (Lee et al. 2007) (please note that in this chapter, we use the nomenclature of Glaser et al. 2006: MLL2/Trx2 and MLL4/ALR. In contrast, some publications designate 
MLL4 as Trx2, whereas MLL2 is designated ALR; e.g., see De Santa et al. 2007; Issaeva et al. 2007; Lee et al. 2007). Depletion of UTX leads to an increased binding of Ring-finger-containing proteins of the PRC1 complex, Bmil and Ring1A, and an increase in H2A monoubiquitylation of HOXA13 and HOXC4 (Lee et al. 2007). However, the depletion of UTX and the concomitant increase in $\mathrm{H} 3 \mathrm{~K} 27$ methylation did not have a significant effect on the occupancy of the HOXA13 and HOXC4 promoters with components of the MLL3/4 (ALR) complex or the methylation status of H3K4 (Lee et al. 2007). Furthermore, UTX was shown to regulate H3K27 methylation in some but not all HOXD genes in HeLa cells (Lan et al. 2007). In particular, H3K $27 \mathrm{me} 3$ levels of the promoter region of HOXD10-12 were elevated following UTX knockdown (Lan et al. 2007). Additionally, the 3' end of HOXD12 had a higher H3K27me3 level in UTX-depleted cells. In contrast, Jmjd3 depletion had little effect on the H3K27me3 status of the HOXD cluster (Lan et al. 2007). In primary human fibroblasts, $90 \%$ of all UTX-binding sites were in $H O X$ loci, independent of their expression status, and concentrated in relatively narrow regions within $500 \mathrm{bp}$ downstream from the transcriptional start site of $H O X$ genes (Lan et al. 2007). In contrast, UTX was entirely excluded from the $H O X$ loci in mouse ES cells where $H O X$ genes are transcriptionally silent and associated with $\mathrm{H} 3 \mathrm{~K} 27 \mathrm{me} 3$ (Lan et al. 2007). Inhibition of the UTX homolog in zebrafish results in misregulation of $H O X$ genes and developmental defects of the posterior trunk (Lan et al. 2007).

\section{H3K27 DEMETHYLASES IN SENESCENCE}

Replicative senescence in human multipotent stem cells is associated with the decreased expression of histone deacetylase 1 and 2 (HDAC1/2) followed by down-regulation of the PcG proteins Ezh2, SUZ12, and Bmil and the up-regulation of Jmjd3 (Jung et al. 2010). As a consequence, the $\mathrm{p} 16^{\mathrm{INK} 4 \mathrm{~A}}$ tumor-suppressor protein gets up-regulated (Jung et al. 2010). Polycomb proteins and Jmjd3 are involved in the homeostasis of the $p 16^{I N K 4 A}$ locus, which has an important role in cellular senescence. In normally growing cells, the INK4A/Arf locus encoding for the tumorsuppressor proteins $\mathrm{p} 16^{\mathrm{INK} 4 \mathrm{~A}}$ and $\mathrm{p} 14^{\mathrm{ARF}}$ (p19 $19^{\mathrm{ARF}}$ in mice) is transcriptionally silenced by $\mathrm{H} 3 \mathrm{~K} 27$ methylation and $\mathrm{PcG}$ binding. In response to oncogenic stress, the INK4A/ARF locus loses H3K27 methylation, which leads to the expression of the $\mathrm{p} 16^{\mathrm{INK} 4 \mathrm{~A}}$ protein and, ultimately, cellular senescence. p16 ${ }^{\mathrm{INK} 4 \mathrm{~A}}$ acts by inhibiting CDK4/6 upstream of the pRB-E2F pathway, whereas p14 ${ }^{\mathrm{ARF}}$ inhibits the p53-specific ubiquitin ligase MDM2 and thereby increases the cellular level of p53 (Gil and Peters 2006). Jmjd3, but not UTX, gets induced by oncogenic stress (BRAF and HRAS ${ }^{12}$ ) approximately fourfold within $2 \mathrm{~h}$ and up to 12-fold during the proceeding 5 days (Agger et al. 2009). In contrast, expression of Ezh2 declined significantly following RAS activation (Agger et al. 2009; Barradas et al. 2009). Jmjd3 binds predominantly just upstream of the transcriptional start site of INK $4 a$, where it leads to H3K27 demethylation and loss of the PcG proteins CBX7,
Bmi1, and SUZ12 (Barradas et al. 2009), thereby reversing Polycomb repression of the locus (Agger et al. 2009). Conversely, Jmjd3 does not bind to or increase expression of the $A R F$ or $I N K 4 b$ promoters (Barradas et al. 2009). Consistent with this, the level of p53, which is stabilized by p14 ${ }^{\mathrm{ARF}}$, was unchanged (Barradas et al. 2009). H3K27 methylation at the INK4a/Arf locus is reduced by 50\% within $3 \mathrm{~d}$ of oncogenic stress and is barely detectable after $7 \mathrm{~d}$ (Barradas et al. 2009). Due to the up-regulation of $I N K 4 A / A r f$, Jmjd 3 acts as a tumor suppressor by leading stressed cells into senescence that, at least in part, counteracts the oncogenic properties of the H3K27 HMT Ezh2. Therefore, overexpression of Jmjd3, but not UTX or loss of PcG proteins, leads to an increased expression of $I N K 4 \mathrm{~A}$ and an inhibition of cell proliferation (Jacobs et al. 1999; Agger et al. 2009; Barradas et al. 2009). Conversely, small hairpin RNA (shRNA)-mediated depletion of Jmjd3 inhibits stress-induced $\mathrm{p} 16^{\mathrm{INK} 4 \mathrm{~A}}$ and $\mathrm{p} 19^{\mathrm{Arf}}$ expression, which leads to immortalization of primary mouse embryonic fibroblasts (MEFs) (Agger et al. 2009). In human fibroblasts, Jmjd 3 activated Ink4A, but not Arf, whereas in MEFs, Jmjd 3 activates both Ink4A and Arf (Barradas et al. 2009).

Similar to Jmjd3, UTX binds predominantly upstream of transcriptional start sites of genes enriched in $\mathrm{H} 3 \mathrm{~K} 4 \mathrm{me} 2$, consistent with the reported association of UTX with MLL4/ALR (Cho et al. 2007; Issaeva et al. 2007; Lan et al. 2007; Lee et al. 2007) and MLL3 (Cho et al. 2007). MLL4/ALR is necessary for UTX occupancy of some, but not all, of its target genes (Issaeva et al. 2007). Importantly, UTX is necessary and sufficient to mediate cell cycle arrest of primary human fibroblasts (Wang et al. 2010). UTX mediates cell cycle arrest by binding to and demethylating 49 genes coding for proteins that bind to the retinoblastoma (RB) tumor suppressor, which inhibits the $\mathrm{G}_{1}-\mathrm{S}$ transition and enforces terminal differentiation (Wang et al. 2010). These proteins are coordinately down-regulated in various human cancers, including human acute myelogenous leukemia and human B-cell lymphomas (Xiang et al. 2007). Furthermore, the $R B$ gene and its related gene $R b l 2$ are direct targets for UTX-dependent H3K27me3 demethylation (Terashima et al. 2010). The prognostic value of UTX is linked to Ezh2 levels: In tumors with low Ezh2, UTX has a significantly larger impact on metastases and patient survival, whereas its impact is small in Ezh2-overexpressing tumors. This suggests that excess Ezh2 or lack of UTX are redundant mechanisms for misregulating H3K27me3 levels in cancer (Xiang et al. 2007).

\section{GENOME-WIDE ANALYSIS OF H3K27 DEMETHYLASES IN HUMAN CANCERS}

Jmjd3 expression levels were found to be low in various types of primary tumors (Agger et al. 2009; Barradas et al. 2009), and the inhibition of $\mathrm{H} 3 \mathrm{~K} 27$ trimethylation has a negative effect on tumor cells (Tan et al. 2007). Therefore, higher Jmjd3 protein level or activity, associated with lower H3K27me3 levels, might be a goal for cancer therapy. Sporadic inactivating somatic mutations of UTX are present in many cancers, with a prevalence of $10 \%$ in multiple myelo- 
Table 1. Overview of the Role of Jmjd3 and UTX in Transcriptional Regulation

\begin{tabular}{lll}
\hline Protein & Function & References \\
\hline Jmjd3 & Activation of the Brachyury locus during ES cell differentiation, mediated by Smad2/3 & Dahle et al. (2010) \\
& following Nodal signaling. & Burgold et al. (2008) \\
& Activation of Pax6, Sox1, and Nestin during neural commitment in differentiating & \\
ES cells. & Akizu et al. (2010) \\
& Smad1/4-dependent H3K27 demethylation of the Noggin promoter following BMP \\
signaling. & Dai et al. (2010) \\
Activation of the Mash1/Ascll gene during neuronal differentiation. & Jepsen et al. (2007) \\
Activation of genes repressed by NCoR2/SMRT during retinoic acid-induced & De Santa et al. (2007, 2009) \\
neuronal differentiation. & Lewis et al. (2007); Miller \\
Activation of a few hundred genes following LPS activation in mouse macrophages. & et al. (2008) \\
Activation of the interferon- $\gamma$ (Ifn- $\gamma$ ) locus following differentiation of T lymphocytes & Sen et al. (2008) \\
into the Th1 lineage. & Shaw and Martin (2009) \\
Activation of genes critical for epidermal differentiation. & Agger et al. (2009); \\
Induction of genes involved in wound healing in murine skin repair. & Barradas et al. (2009); \\
Activation of the INK4A tumor-suppressor locus following oncogenic stress and & Jung et (2010) \\
senescence. & Seenundun et al. (2010) \\
& Agger et al. (2007); Lee \\
Activation of myogenin and muscle creatine kinase during myogenesis. & et al. (2007) \\
Demethylation of $H O X A 1-3$ and $H O X B 1-3$ genes during retinoic acid-induced & Lan et al. (2007) \\
differentiation of human pluripotent cells. & Wang et al. (2010) \\
Regulation of $H O X D 10-12$ in HeLa cells (exclusive to UTX; no involvement of Jmjd3). &
\end{tabular}

ma, $8 \%$ in esophageal squamous cell carcinomas, and $1.4 \%$ in renal cell carcinomas (van Haaften et al. 2009; Dalgliesh et al. 2010). Induction of UTX expression in UTX null cancer cells reduced $\mathrm{H} 3 \mathrm{~K} 27 \mathrm{me} 3$ and slowed cell proliferation (van Haaften et al. 2009). Down-regulation of Jmjd3 was found in lung and liver cancers (Agger et al. 2009; Barradas et al. 2009). However, despite the evidence that HDMs might act as tumor suppressors, it remains to be determined whether observed mutations are a cause or consequence of tumorigenesis. Similar to down-regulation of Jmjd3, up-regulation of the H3K27 HMT Ezh2 was found to be a prognostic marker for aggressive breast cancer and a promoter of neoplastic transformation of breast epithelial cells (Kleer et al. 2003; Cao et al. 2008). Similarly, Ezh2 is up-regulated in aggressive prostate tumors, where it transforms benign prostate epithelial cells (Varambally et al. 2002; Yu et al. 2007), bronchial cancer (Breuer et al. 2004), melanoma (Bachmann et al. 2006), bladder cancer (Weikert et al. 2005), and liver cancer (Sudo et al. 2005). Conversely, Jmjd3 is upregulated in prostate cancers and is highest in metastatic tumors (Xiang et al. 2007).

\section{CONCLUSIONS}

It has become clear in recent years that histone methylation is not an irreversible chromatin modification and that HMTs and demethylases mediate the steady-state level of histone methylation on one hand and the plasticity for changes in gene expression on the other hand (see Table 1). However, how dynamic the methylation status of a single histone protein really is during the cell cycle, differentiation, or transcription remains to be determined. How histone demethylase activity is regulated is largely unknown and will be pivotal to our understanding of the interplay between histone methylation and demethylation. Long noncoding
RNAs have recently been shown to be a component of histone-modification complexes (Tsai et al. 2010), but whether they have an active regulatory role or merely a structural function is unknown. Furthermore, the dynamic changes of other histone modifications and how they influence histone methylation are also largely unknown. Finally, further studies will determine whether histone demethylases have additional role(s) in transcriptional regulation that are independent of their catalytic activity or whether they regulate other nonhistone substrates.

\section{ACKNOWLEDGMENTS}

Research in D.L.S.'s laboratory is funded by National Institutes of Health (NIH) grant NIGMS42694, NIH/ National Cancer Institute grant 5POICA013106, and NIH/EY grant 18244. M.R.H. was supported by fellowships from the European Molecular Biology Organization (EMBO; ALTF 160-2005) and the German Academic Exchange Service (DAAD).

\section{REFERENCES}

Agger K, Cloos PA, Christensen J, Pasini D, Rose S, Rappsilber J, Issaeva I, Canaani E, Salcini AE, Helin K. 2007. UTX and JMJD3 are histone H3K27 demethylases involved in HOX gene regulation and development. Nature 449: 731-734.

Agger K, Cloos PA, Rudkjaer L, Williams K, Andersen G, Christensen J, Helin K. 2009. The H3K27me3 demethylase JMJD3 contributes to the activation of the INK $4 A-A R F$ locus in response to oncogene- and stress-induced senescence. Genes Dev 23: 1171-1176.

Akizu N, Estaras C, Guerrero L, Marti E, Martinez-Balbas MA. 2010. H3K27me3 regulates BMP activity in developing spinal cord. Development 137: 2915-2925.

Bachmann IM, Halvorsen OJ, Collett K, Stefansson IM, Straume O, Haukaas SA, Salvesen HB, Otte AP, Akslen LA. 2006. EZH2 expression is associated with high proliferation rate and aggres- 
sive tumor subgroups in cutaneous melanoma and cancers of the endometrium, prostate, and breast. J Clin Oncol 24: 268-273.

Barradas M, Anderton E, Acosta JC, Li S, Banito A, RodriguezNiedenfuhr M, Maertens G, Banck M, Zhou MM, Walsh MJ, et al. 2009. Histone demethylase JMJD3 contributes to epigenetic control of INK4a/ARF by oncogenic RAS. Genes Dev 23: 1177-1182.

Bernstein BE, Mikkelsen TS, Xie X, Kamal M, Huebert DJ, Cuff J, Fry B, Meissner A, Wernig M, Plath K, et al. 2006. A bivalent chromatin structure marks key developmental genes in embryonic stem cells. Cell 125: 315-326.

Blanpain C, Fuchs E. 2006. Epidermal stem cells of the skin. Annu Rev Cell Dev Biol 22: 339-373.

Blatch GL, Lassle M. 1999. The tetratricopeptide repeat: A structural motif mediating protein-protein interactions. Bioessays 21: 932-939.

Boyer LA, Plath K, Zeitlinger J, Brambrink T, Medeiros LA, Lee TI, Levine SS, Wernig M, Tajonar A, Ray MK, et al. 2006. Polycomb complexes repress developmental regulators in murine embryonic stem cells. Nature 441: 349-353.

Bracken AP, Dietrich N, Pasini D, Hansen KH, Helin K. 2006. Genome-wide mapping of Polycomb target genes unravels their roles in cell fate transitions. Genes Dev 20: 1123-1136.

Breuer RH, Snijders PJ, Smit EF, Sutedja TG, Sewalt RG, Otte AP, van Kemenade FJ, Postmus PE, Meijer CJ, Raaphorst FM. 2004. Increased expression of the $E Z H 2$ Polycomb group gene in BMI-1-positive neoplastic cells during bronchial carcinogenesis. Neoplasia 6: 736-743.

Burgold T, Spreafico F, De Santa F, Totaro MG, Prosperini E, Natoli G, Testa G. 2008. The histone H3 lysine 27-specific demethylase Jmjd3 is required for neural commitment. PLoS One 3: e3034.

Cao Q, Yu J, Dhanasekaran SM, Kim JH, Mani RS, Tomlins SA, Mehra R, Laxman B, Cao X, Kleer CG, et al. 2008. Repression of E-cadherin by the Polycomb group protein EZH2 in cancer. Oncogene 27: 7274-7284.

Cho YW, Hong T, Hong S, Guo H, Yu H, Kim D, Guszczynski T, Dressler GR, Copeland TD, Kalkum M, et al. 2007. PTIP associates with MLL3- and MLL4-containing histone H3 lysine 4 methyltransferase complex. J Biol Chem 282: 20395-20406.

Cloos PA, Christensen J, Agger K, Helin K. 2008. Erasing the methyl mark: Histone demethylases at the center of cellular differentiation and disease. Genes Dev 22: 1115-1140.

Dahle O, Kumar A, Kuehn MR. 2010. Nodal signaling recruits the histone demethylase Jmjd3 to counteract Polycomb-mediated repression at target genes. Sci Signal 3: ra48.

Dai JP, Lu JY, Zhang Y, Shen YF. 2010. Jmjd3 activates Mash1 gene in RA-induced neuronal differentiation of $\mathrm{P} 19$ cells. $J$ Cell Biochem 110: 1457-1463.

Dalgliesh GL, Furge K, Greenman C, Chen L, Bignell G, Butler A, Davies H, Edkins S, Hardy C, Latimer C, et al. 2010. Systematic sequencing of renal carcinoma reveals inactivation of histone modifying genes. Nature 463: 360-363.

De Santa F, Totaro MG, Prosperini E, Notarbartolo S, Testa G, Natoli G. 2007. The histone H3 lysine-27 demethylase Jmjd3 links inflammation to inhibition of Polycomb-mediated gene silencing. Cell 130: 1083-1094.

De Santa F, Narang V, Yap ZH, Tusi BK, Burgold T, Austenaa L, Bucci G, Caganova M, Notarbartolo S, Casola S, et al. 2009. Jmjd3 contributes to the control of gene expression in LPS-activated macrophages. EMBO J 28: 3341-3352.

Fang R, Barbera AJ, Xu Y, Rutenberg M, Leonor T, Bi Q, Lan F, Mei P, Yuan GC, Lian C, et al. 2010. Human LSD2/KDM1b/ AOF1 regulates gene transcription by modulating intragenic H3K4me2 methylation. Mol Cell 39: 222-233.

Francis NJ, Kingston RE, Woodcock CL. 2004. Chromatin compaction by a Polycomb group protein complex. Science 306: 1574-1577.

Gil J, Peters G. 2006. Regulation of the INK4b-ARF-INK4a tumour suppressor locus: All for one or one for all. Nat Rev Mol Cell Biol 7: 667-677.

Glaser S, Schaft J, Lubitz S, Vintersten K, van der Hoeven F, Tufteland KR, Aasland R, Anastassiadis K, Ang SL, Stewart AF.
2006. Multiple epigenetic maintenance factors implicated by the loss of Mll2 in mouse development. Development 133: 1423-1432.

Greenfield A, Carrel L, Pennisi D, Philippe C, Quaderi N, Siggers P, Steiner K, Tam PP, Monaco AP, Willard HF, et al. 1998. The UTX gene escapes X inactivation in mice and humans. Hum Mol Genet 7: 737-742.

Hong S, Cho YW, Yu LR, Yu H, Veenstra TD, Ge, K. 2007. Identification of JmjC domain-containing UTX and JMJD3 as histone H3 lysine 27 demethylases. Proc Natl Acad Sci 104: 18439-18444.

Huang J, Berger SL. 2008. The emerging field of dynamic lysine methylation of non-histone proteins. Curr Opin Genet Dev 18: $152-158$.

Ishii M, Wen H, Corsa CA, Liu T, Coelho AL, Allen RM, Carson WF IV, Cavassani KA, Li X, Lukacs NW, et al. 2009. Epigenetic regulation of the alternatively activated macrophage phenotype. Blood 114: 3244-3254.

Issaeva I, Zonis Y, Rozovskaia T, Orlovsky K, Croce CM, Nakamura T, Mazo A, Eisenbach L, Canaani E. 2007. Knockdown of ALR (MLL2) reveals ALR target genes and leads to alterations in cell adhesion and growth. Mol Cell Biol 27: 18891903.

Jacobs JJ, Kieboom K, Marino S, DePinho RA, van Lohuizen M. 1999. The oncogene and Polycomb-group gene bmi-1 regulates cell proliferation and senescence through the ink $4 a$ locus. $\mathrm{Na}$ ture 397: 164-168.

Jepsen K, Solum D, Zhou T, McEvilly RJ, Kim HJ, Glass CK, Hermanson O, Rosenfeld MG. 2007. SMRT-mediated repression of an H3K27 demethylase in progression from neural stem cell to neuron. Nature 450: 415-419.

Jung JW, Lee S, Seo MS, Park SB, Kurtz A, Kang SK, Kang KS. 2010. Histone deacetylase controls adult stem cell aging by balancing the expression of polycomb genes and jumonji domain containing 3. Cell Mol Life Sci 67: 1165-1176.

Kleer CG, Cao Q, Varambally S, Shen R, Ota I, Tomlins SA, Ghosh D, Sewalt RG, Otte AP, Hayes DF, et al. 2003. EZH2 is a marker of aggressive breast cancer and promotes neoplastic transformation of breast epithelial cells. Proc Natl Acad Sci 100: 11606-11611.

Klose RJ, Zhang Y. 2007. Regulation of histone methylation by demethylimination and demethylation. Nat Rev Mol Cell Biol 8: $307-318$.

Klose RJ, Kallin EM, Zhang Y. 2006. JmjC-domain-containing proteins and histone demethylation. Nat Rev Genet 7: 715-727.

$\mathrm{Ku}$ M, Koche RP, Rheinbay E, Mendenhall EM, Endoh M, Mikkelsen TS, Presser A, Nusbaum C, Xie X, Chi AS, et al. 2008. Genomewide analysis of PRC1 and PRC2 occupancy identifies two classes of bivalent domains. PLoS Genet 4: e1000242.

Lan F, Bayliss PE, Rinn JL, Whetstine JR, Wang JK, Chen S, Iwase S, Alpatov R, Issaeva I, Canaani E, et al. 2007. A histone H3 lysine 27 demethylase regulates animal posterior development. Nature 449: 689-694.

Lan F, Nottke AC, Shi Y. 2008. Mechanisms involved in the regulation of histone lysine demethylases. Curr Opin Cell Biol 20: 316-325.

Lee TI, Jenner RG, Boyer LA, Guenther MG, Levine SS, Kumar RM, Chevalier B, Johnstone SE, Cole MF, Isono K, et al. 2006. Control of developmental regulators by Polycomb in human embryonic stem cells. Cell 125: 301-313.

Lee MG, Villa R, Trojer P, Norman J, Yan KP, Reinberg D, Di Croce L, Shiekhattar R. 2007. Demethylation of H3K27 regulates polycomb recruitment and $\mathrm{H} 2 \mathrm{~A}$ ubiquitination. Science 318: $447-450$

Lewis MD, Miller SA, Miazgowicz MM, Beima KM, Weinmann AS. 2007. T-bet's ability to regulate individual target genes requires the conserved T-box domain to recruit histone methyltransferase activity and a separate family member-specific transactivation domain. Mol Cell Biol 27: 8510-8521.

Liu A, Niswander LA. 2005. Bone morphogenetic protein signalling and vertebrate nervous system development. Nat Rev Neurosci 6: 945-954. 
Margueron R, Li G, Sarma K, Blais A, Zavadil J, Woodcock CL, Dynlacht BD, Reinberg D. 2008. Ezh1 and Ezh2 maintain repressive chromatin through different mechanisms. Mol Cell 32: 503-518.

Mikkelsen TS, Ku M, Jaffe DB, Issac B, Lieberman E, Giannoukos G, Alvarez P, Brockman W, Kim TK, Koche RP, et al. 2007. Genome-wide maps of chromatin state in pluripotent and lineage-committed cells. Nature 448: 553-560.

Miller SA, Huang AC, Miazgowicz MM, Brassil MM, Weinmann AS. 2008. Coordinated but physically separable interaction with H3K27-demethylase and H3K4-methyltransferase activities are required for T-box protein-mediated activation of developmental gene expression. Genes Dev 22: 2980-2993.

Mosammaparast N, Shi Y. 2010. Reversal of histone methylation: Biochemical and molecular mechanisms of histone demethylases. Annu Rev Biochem 79: 155-179.

Pan G, Tian S, Nie J, Yang C, Ruotti V, Wei H, Jonsdottir GA, Stewart R, Thomson JA. 2007. Whole-genome analysis of histone $\mathrm{H} 3$ lysine 4 and lysine 27 methylation in human embryonic stem cells. Cell Stem Cell 1: 299-312.

Papp B, Muller J. 2006. Histone trimethylation and the maintenance of transcriptional ON and OFF states by trxG and PcG proteins. Genes Dev 20: 2041-2054.

Pietersen AM, van Lohuizen M. 2008. Stem cell regulation by polycomb repressors: Postponing commitment. Curr Opin Cell Biol 20: 201-207.

Plath K, Fang J, Mlynarczyk-Evans SK, Cao R, Worringer KA, Wang H, de la Cruz CC, Otte AP, Panning B, Zhang Y. 2003. Role of histone $\mathrm{H} 3$ lysine 27 methylation in X inactivation. Science 300: 131-135.

Ringrose L, Paro R. 2004. Epigenetic regulation of cellular memory by the Polycomb and Trithorax group proteins. Annu Rev Genet 38: 413-443.

Roh TY, Cuddapah S, Cui K, Zhao K. 2006. The genomic landscape of histone modifications in human T cells. Proc Natl Acad Sci 103: 15782-15787.

Satoh T, Takeuchi O, Vandenbon A, Yasuda K, Tanaka Y, Kumagai Y, Miyake T, Matsushita K, Okazaki T, Saitoh T, et al. 2010. The Jmjd3-Irf4 axis regulates M2 macrophage polarization and host responses against helminth infection. Nat Immunol. 11: 936944.

Schoenborn JR, Dorschner MO, Sekimata M, Santer DM, Shnyreva M, Fitzpatrick DR, Stamatoyannopoulos JA, Wilson CB 2007. Comprehensive epigenetic profiling identifies multiple distal regulatory elements directing transcription of the gene encoding interferon- $\gamma$. Nat Immunol 8: 732-742.

Schuettengruber B, Cavalli G. 2009. Recruitment of Polycomb group complexes and their role in the dynamic regulation of cell fate choice. Development 136: 3531-3542.

Schuettengruber B, Chourrout D, Vervoort M, Leblanc B, Cavalli G. 2007. Genome regulation by Polycomb and Trithorax proteins. Cell 128: 735-745.

Schwartz YB, Pirrotta V. 2007. Polycomb silencing mechanisms and the management of genomic programmes. Nat Rev Genet 8: $9-22$.

Seenundun S, Rampalli S, Liu QC, Aziz A, Palii C, Hong S, Blais A, Brand M, Ge K, Dilworth FJ. 2010. UTX mediates demethylation of $\mathrm{H} 3 \mathrm{~K} 27 \mathrm{me} 3$ at muscle-specific genes during myogenesis. EMBO J 29: 1401-1411.

Sen GL, Webster DE, Barragan DI, Chang HY, Khavari PA. 2008. Control of differentiation in a self-renewing mammalian tissue by the histone demethylase JMJD3. Genes Dev 22: 1865-1870.

Shaw T, Martin P. 2009. Epigenetic reprogramming during wound healing: Loss of Polycomb-mediated silencing may enable upregulation of repair genes. EMBO Rep 10: 881-886.
Shen X, Liu Y, Hsu YJ, Fujiwara Y, Kim J, Mao X, Yuan GC, Orkin SH. 2008. EZH1 mediates methylation on histone H3 lysine 27 and complements EZH2 in maintaining stem cell identity and executing pluripotency. Mol Cell 32: 491-502.

Shi Y, Whetstine JR. 2007. Dynamic regulation of histone lysine methylation by demethylases. Mol Cell 25: 1-14.

Shi Y, Lan F, Matson C, Mulligan P, Whetstine JR, Cole PA, Casero RA. 2004. Histone demethylation mediated by the nuclear amine oxidase homolog LSD1. Cell 119: 941-953.

Simon JA, Kingston RE. 2009. Mechanisms of Polycomb gene silencing: Knowns and unknowns. Nat Rev Mol Cell Biol 10: 697-708.

Smith ER, Lee MG, Winter B, Droz NM, Eissenberg JC, Shiekhat$\operatorname{tar}$ R, Shilatifard A. 2008. Drosophila UTX is a histone H3 Lys27 demethylase that colocalizes with the elongating form of RNA polymerase II. Mol Cell Biol 28: 1041-1046.

Sudo T, Utsunomiya T, Mimori K, Nagahara H, Ogawa K, Inoue H, Wakiyama S, Fujita H, Shirouzu K, Mori M. 2005. Clinicopathological significance of EZH2 mRNA expression in patients with hepatocellular carcinoma. Br J Cancer 92: 1754 1758.

Tan J, Yang X, Zhuang L, Jiang X, Chen W, Lee PL, Karuturi RK, Tan PB, Liu ET, Yu Q. 2007. Pharmacologic disruption of Polycomb-repressive complex 2-mediated gene repression selectively induces apoptosis in cancer cells. Genes Dev 21: 1050 1063.

Terashima M, Ishimura A, Yoshida M, Suzuki Y, Sugano S, Suzuki T. 2010. The tumor suppressor $\mathrm{Rb}$ and its related Rbl2 genes are regulated by Utx histone demethylase. Biochem Biophys Res Coтmun 399: 238-244.

Tsai MC, Manor O, Wan Y, Mosammaparast N, Wang JK, Lan F, Shi Y, Segal E, Chang HY. 2010. Long noncoding RNA as modular scaffold of histone modification complexes. Science 329: 689-693.

van Haaften G, Dalgliesh GL, Davies H, Chen L, Bignell G, Greenman C, Edkins S, Hardy C, O'Meara S, Teague J, et al. 2009. Somatic mutations of the histone H3K27 demethylase gene UTX in human cancer. Nat Genet 41: 521-523.

Varambally S, Dhanasekaran SM, Zhou M, Barrette TR, KumarSinha C, Sanda MG, Ghosh D, Pienta KJ, Sewalt RG, Otte AP, et al. 2002. The polycomb group protein EZH2 is involved in progression of prostate cancer. Nature 419: 624-629.

Wang JK, Tsai MC, Poulin G, Adler AS, Chen S, Liu H, Shi Y, Chang HY. 2010. The histone demethylase UTX enables RBdependent cell fate control. Genes Dev 24: 327-332.

Weikert S, Christoph F, Kollermann J, Muller M, Schrader M, Miller K, Krause H. 2005. Expression levels of the EZH2 polycomb transcriptional repressor correlate with aggressiveness and invasive potential of bladder carcinomas. Int J Mol Med 16: 349-353.

Xiang Y, Zhu Z, Han G, Lin H, Xu L, Chen CD. 2007. JMJD3 is a histone H3K27 demethylase. Cell Res 17: 850-857.

Yu J, Cao Q, Mehra R, Laxman B, Tomlins SA, Creighton CJ, Dhanasekaran SM, Shen R, Chen G, Morris DS, et al. 2007. Integrative genomics analysis reveals silencing of $\beta$-adrenergic signaling by Polycomb in prostate cancer. Cancer Cell 12: 419 431 .

Zhao XD, Han X, Chew JL, Liu J, Chiu KP, Choo A, Orlov YL, Sung WK, Shahab A, Kuznetsov VA, et al. 2007. Wholegenome mapping of histone H3 Lys4 and 27 trimethylations reveals distinct genomic compartments in human embryonic stem cells. Cell Stem Cell 1: 286-298.

Zhao J, Sun BK, Erwin JA, Song JJ, Lee JT. 2008. Polycomb proteins targeted by a short repeat RNA to the mouse X chromosome. Science 322: 750-756. 


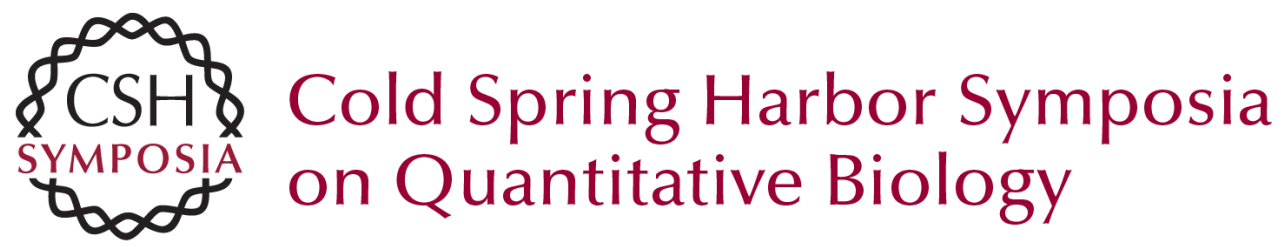

\section{Role of H3K27 Demethylases Jmjd3 and UTX in Transcriptional Regulation}

M.R. Hübner and D.L. Spector

Cold Spring Harb Symp Quant Biol 2010 75: 43-49 originally published online January 5, 2011 Access the most recent version at doi:10.1101/sqb.2010.75.020

References This article cites 77 articles, 27 of which can be accessed free at: http://symposium.cshlp.org/content/75/43.full.html\#ref-list-1

\section{License}

Email Alerting Service top right corner of the article or click here.

To subscribe to Cold Spring Harbor Symposia on Quantitative Biology go to: http://symposium.cshlp.org/subscriptions 